\author{
JÓZEF KOREDCZUK \\ ORCID: 0000-0002-3471-568X \\ Uniwersytet Wrocławski \\ Instytut Historii Państwa i Prawa \\ Zakład Powszechnej Historii Państwa i Prawa
}

\title{
PROBLEM INTABULACJI PRAWA WŁASNOŚCI NIERUCHOMOŚCI W POLSCE (W BYŁYM ZABORZE AUSTRIACKIM) W OKRESIE MIĘDZYWOJENNYM
}

\begin{abstract}
Abstrakt: Intabulacja, czyli wpisanie prawa własności nieruchomości do księgi gruntowej w prawie obowiązującym w byłym zaborze austriackim w Polsce w okresie międzywojennym, miała niezwykle istotne znaczenie. Była jednym z warunków skutecznego przeniesienia tego prawa. Dotyczy to także przeniesienia prawa własności nieruchomości w drodze dziedziczenia. W praktyce niestety często jej nie dokonywano, co powodowało niezgodność między faktycznym a prawnym stanem władania nieruchomościami, z którymi nawet sądy musiały się godzić. Sytuacja taka występowała w byłym zaborze austriackim, szczególnie odnośnie do dziedziczenia gruntów chłopskich, rodząc wiele problemów prawnych.
\end{abstract}

Słowa kluczowe: ABGB, dziedziczenie, intabulacja, księga gruntowa, przeniesienie własności, własność nieruchomości

Intabulacja (łac. intabulatio) oznacza wpisanie (własności) do księgi wieczystej (hipotecznej). Wpis ten był niezwykle ważny, ponieważ był jednym z warunków skutecznego przeniesienia prawa własności nieruchomości, które na ziemiach byłego zaboru austriackiego w okresie międzywojennym mogło być w różny sposób przenoszone. Jednym ze sposobów przeniesienia prawa własności nieruchomości, na którym pragnę się skupić w niniejszym przyczynku, było spadkobranie.

Kodeks cywilny austriacki z 1811 roku ${ }^{1}$ do przeniesienia własności wymagał ważnego tytułu prawnego (titulus) oraz sposobu przeniesienia własności (modus acquirendi domini), który przy nieruchomościach polegał na wpisie do księgi

1 Allgemeines Bürgerliches Gesetzbuch - Patent cesarski z dnia 1 czerwca 1811 roku Powszechna księga ustaw cywilnych dla wszystkich krajów dziedzicznych niemieckich Monarchii Austryiackiej (Dz.U.P. nr 87, 472). 
gruntowej (wieczystej) ${ }^{2}$. Stanowił to wprost $\S 431$ ABGB, który przewidywał, iż w celu przeniesienia własności rzeczy nieruchomych nastąpić musi wpis aktu ich nabycia do przeznaczonych na to ksiąg publicznych. A wpis ten nazywa się wpisem hipotecznym (intabulacją) $)^{3}$. Wpis prawa własności spadkobierców do księgi gruntowej, jak wspomniałem, miał niezwykle istotne znaczenie. By jednak instytucja ksiąg gruntowych mogła spełniać cele, dla których powstała i rozwinęła się, to jest zabezpieczenie obrotu prawnego nieruchomościami, to powinna zawsze, w sposób zgodny z prawdą i w zupełności bez reszty, ujawniać stan prawny dotyczący nieruchomości przynajmniej w zakresie praw rzeczowych, a więc także spadkowych. Do tego dążyła tak zwana zasada wpisu, której urzeczywistnienie wymagało spełnienia dwóch warunków: 1) bez wpisu nie może nastąpić żadna zmiana w zakresie praw rzeczowych (das absolute Eintragungsprinzip); 2) każdy wpis musi mieć moc prawną, musi uchodzić za zgodny ze stanem prawnym (die formale Rechtskraft der Eintragungen). Warunek ten w terminologii austriackiej nazywany był pozytywną stroną jawności materialnej ksiąg gruntowych ${ }^{4}$.

W następstwie wpisu prawa własności spadkobierców do księgi gruntowej dokonywało się przeniesienie prawa własności nieruchomości. Była to tak zwana sukcesja szczególna, w ramach której wpis nieruchomości do księgi gruntowej spełniał taką samą funkcję jak tradycja (traditio) przy przeniesieniu własności ruchomości ${ }^{5}$. W wyniku spadkobrania następowało przeniesienie prawa własności rzeczy, które były przedmiotem spadku. Przepis § 431 ABGB w odniesieniu do nieruchomości wprowadzał zasadę, że sposobem (modus) nabycia własności nieruchomości było wniesienie tytułu nabycia do ksiąg publicznych do tego przeznaczonych, czyli intabulacja. Był to warunek konieczny skuteczności przeniesienia prawa własności nieruchomości. W konsekwencji w ABGB wprowadzono — w odniesieniu do nieruchomości — rzymską zasadę traditio, tyle że sposób jej realizacji odbiegał w istotnym stopniu od klasycznych założeń tej instytucji. Niemniej pozwalał on na pełne urzeczywistnienie zasady jawności obrotu nieruchomościami, a więc zmierzał do osiągnięcia celu, z którym nie do końca radziła sobie rzymska traditio ${ }^{6}$. Zasady prowadzenia ksiąg gruntowych w byłym zaborze austriackim uregulowała dopiero ustawa z dnia 25 lipca 1871 roku o księgach gruntowych (Das allgemeine Grundbuchsgesetz, d.p.p. nr 95), która wprowadziła zasadę wiarygodności wszelkich wpisów dokonanych do ksiąg gruntowych, oraz

2 E. Drozd, Przeniesienie własności nieruchomości, Warszawa-Kraków 1974, s. 15.

3 S. Breyer, Przeniesienie własności nieruchomości, Warszawa 1975, s. 31.

${ }^{4}$ F. Zoll, Na marginesie projektu prawa rzeczowego. Zasada wpisu a posiadanie prawne, „Kwartalnik Prawa Prywatnego” 1, 1938, z. 1, s. 19-20.

5 L. Górnicki, Prawa rzeczowe, [w:] Synteza prawa polskiego 1918-1939, red. T. Guz, J. Głuchowski, M.R. Pałubska, Warszawa 2013, s. 326.

${ }^{6}$ P. Blajer, Traditio a zasada jawności obrotu nieruchomościami, [w:] Experientia docet. Księga jubileuszowa ofiarowana Pani Profesor Elżbiecie Traple, red. P. Kostański, P. Podrecki, T. Targosz, Warszawa 2017, s. 859. 
wydana na jej podstawie ustawa krajowa z dnia 20 marca 1874 roku o założeniu ksiąg gruntowych (Dziennik Ustaw i Rozporządzeń Krajowych dla Królestwa Galicji i Lodomerii $\mathrm{nr} 29$, s. 89) ${ }^{7}$. Praktyczna realizacja obu wymienionych ustaw zależna była od uaktualnienia danych zawartych w dotychczasowych księgach (na przykład tablicach ziemskich), przede wszystkim w zakresie stanu faktycznego opisanych w nich nieruchomości ${ }^{8}$.

Mimo wydania wspomnianych aktów prawnych i formalnie przewidzianego w nich obowiązku potwierdzania w księgach gruntowych wszelkich zmian co do prawa własności nieruchomości nie spowodowały one całkowitego upowszechnienia ksiąg gruntowych, zwłaszcza dla gruntów chłopskich, odnośnie do których nadal ogromne znaczenie miało przenoszenie własności ziemi przez prostą tradycję — poprzez nierejestrowane działy spadkowe. Praktyka ta niosła za sobą pewne niebezpieczeństwo - nierzadkie były przypadki usuwania niezaintabulowanych chłopów z ich ziemi przez nabywców hipotecznych, nawet jeśli nabyli ową chłopską ziemię od nieuprawnionych osób ${ }^{9}$.

Intabulacja lub złożenie stosownego dokumentu była konieczna nie tylko w przypadku przeniesienia własności nieruchomości w drodze umowy, lecz także w przypadku przeniesienia własności nieruchomości lub budynku na podstawie prawomocnego wyroku, podziału sądowego lub przyznania spadku (§ 436 ABGB). Mimo że przywoływany przepis ABGB wymieniał i intabulację, i złożenie dokumentu jako formalne wymogi niezbędne do nabycia praw rzeczowych na nieruchomości, to jednak zachodziły pomiędzy nimi istotne różnice. Niektórzy z prawników w praktyce, którzy uważali „złożenie” za coś prawie identycznego z intabulacją, często opatrywali je wyrażeniem ,złożenie ... ze skutkiem intabulacji”. Autorzy takich dokumentów uważali „złożenie” za surogat intabulacji. Była to praktyka i rozumowanie całkowicie sprzeczne z literą prawa. Samo złożenie stosownego dokumentu nie dawało nigdy ,zaufania” co do jego skuteczności, gdyż nie stwarzało „posiadania tabularnego" ani nie dawało domniemania, iż nabywca nieruchomości stał się jej właścicielem, czyli tego wszystkiego, co dawała intabulacja. Mimo to - w praktyce - instytucja ,złożenia dokumentu” także miała zastosowanie w stosunku do nieruchomości, co do których nie można było dokonać intabulacji. Dawała ona nabywcy nieruchomości pewne zabezpieczenie w stosunku do roszczeń zgłaszanych do niej przez inne osoby ${ }^{10}$. Logiczny wywód wskazujący na sens

${ }^{7}$ L. Górnicki, Problem prawnej ochrony własności nieruchomości, nie wpisanej do ksiag gruntowych w okresie zaborów i w Polsce niepodległej, „Prawo. Studia Historycznoprawne” 286, 2002, s. $170,180-181$.

8 P. Blajer, Z historii ksiag gruntowych (Grundbücher), „Studia Prawnicze. Rozprawy i Materiały" 2015 , nr 2, s. 97.

9 T. Stawecki, Rejestry nieruchomości, księgi hipoteczne i księgi wieczyste od czasów najdawniejszych do XXI wieku, „Studia Iuridica” 2002, nr 40, s. 192-193.

${ }^{10}$ R. Giżowski, Złożenie dokumentu w sadzie celem nabycia praw rzeczowych na nieruchomości, „Przegląd Notarjalny” (dalej: PN) 11, 1932, z. 2, s. 213, 215. 
skorzystania z instytucji „złożenia dokumentu” dała Izba III Sądu Najwyższego w orzeczeniu z dnia 18 kwietnia 1928 roku (Rw. 2249/27), w którym stwierdziła, że jeżeli „złożony” dokument sam przez się, nawet bez jego „złożenia”, nie uzasadniał praw nabywcy nieruchomości, to wówczas jego „złożenie” w niczym nie polepszało położenia nabywcy. $\mathrm{Z}$ drugiej zaś strony, jeżeli przedmiotowy dokument uzasadniał jego prawo, to nie potrzebował on jego ,złożenia ${ }^{11}$ ”.

Podobną moc, niedającą pełnego zaufania, miało także poświadczenie wydane przez komisarza dla odnowienia ksiąg gruntowych, w którym stwierdzał on, że pewna osoba będzie zaintabulowana jako właściciel danej parceli. Zgodnie z orzeczeniem Sądu Najwyższego z dnia 14 grudnia 1936 roku (C II 1810/36), w sprawie wcześniej rozpatrywanej przez Sąd Okręgowy we Lwowie (I 1 Cg J 1095/31) i Sąd Apelacyjny we Lwowie (I CA 912/35), w którym stwierdził on, że takie poświadczenie nie stanowi ani surogatu księgi gruntowej, ani wypisu z tej księgi, dlatego wykazujący się takim poświadczeniem nie może się powoływać na dobrą wiarę i zaufanie do ksiąg gruntowych ${ }^{12}$.

Przyznanie spadku dziedzicom następowało na podstawie uchwały sądu spadkowego, by mógł być on wpisany do ksiąg, zgodnie z § 436 ABGB, uchwała ta musiała być prawomocna. Jej prawomocność następowała bądź na skutek upływu terminu na wniesienie odwołania (rekursu), bądź utrzymania w mocy przez sąd odwoławczy uchwały sądu spadkowego. Uchwała sądu spadkowego miała dla spadkobierców niezwykle istotne znaczenie, zwłaszcza, gdy nie było założonych prawidłowo ksiąg publicznych. Była ona wtedy, zgodnie z § 1468 ABGB, jednym z dokumentów, za pomocą którego dana osoba mogła udowodnić nabycie rzeczy nieruchomych. Musiała ona jednak spełniać wszelkie wymogi przewidziane w $\S 433$ ABGB odnoszące się do dokumentu przenoszącego własność nieruchomości, czyli zawierać dokładne dane dotyczące osób przenoszących i odbierających własność nieruchomości, którą ma się oddać, wraz z jej częściami składowymi; podstawę prawną oddania; miejsce i czas zawarcia umowy (wydania uchwały przez sąd spadkowy). Paragraf 433 ABGB wymagał ponadto, by w umowie przenoszącej własność nieruchomości jej oddawca w tym lub osobnym dokumencie złożył wyraźne oświadczenie, że zezwala na intabulację. W przypadku przeniesienia własności nieruchomości w drodze dziedziczenia trudno było wymagać takiego oświadczenia. W praktyce czasami zdarzały się odwrotne sytuacje — spadkodawca wyrażał zgodę na przeniesienie jakiejś rzeczy na spadkobiercę, ale nie wyrażał zgody na jej zaintabulowanie na rzecz spadkobiercy.

Kwestię intabulacji dekretu dziedzictwa i środków prawnych w takich sprawach regulowały przepisy ustawy z 1871 roku o księgach gruntowych. Próbując ominąć jej przepisy, usiłowano podważyć intabulację dekretu dziedzictwa, powo-

11 „Przegląd Prawa i Administracji” (dalej: PPiA), „Orzecznictwo w zakresie Małopolski”, 53, 1928, poz. 111, s. 169.

12 PPiA, „Orzecznictwo” 62, 1937, poz. 85, s. 147-148. 
łując się na $§ 177$ pat. niesp. ${ }^{13}$, który, podobnie jak w ABGB, jedyny warunek, jaki stawiał przed dekretem dziedzictwa, by mógł być on wpisany do ksiąg, było to, by był on prawomocny. Izba III Sądu Najwyższego w orzeczeniu z dnia 15 maja 1923 roku (R. 199/23) uznała jednakże taką praktykę za niedopuszczalną ${ }^{14}$. Z uwagi na fakt, że pozytywna strona jawności materialnej ksiąg gruntowych przewidziana w ustawie o księgach gruntowych ograniczała się nie tylko do zasady ich wiarygodności, oprócz wpisu musiały zostać spełnione jeszcze dwa warunki, by wpis ten był skuteczny — ważny tytuł (titulus acquirendi), czyli samoistne zdarzenie prawne uzasadniające po stronie dotychczasowego właściciela (spadkobiercy) obowiązek przeniesienia własności, oraz prawo poprzednika (spadkodawcy), to znaczy wymóg, aby poprzednik był właścicielem ${ }^{15}$.

Zgodnie z $§ 437$ ABGB intabulacja była również konieczna do nabycia własności nieruchomości lub budynku stanowiącego legat, aby było możliwe oddanie rzeczy legatariuszowi. Dopóki dany dziedzic jako współwłaściciel odziedziczonych części spadku nie był wpisany do księgi gruntowej, to nie mógł, zgodnie z orzeczeniem Sądu Najwyższego z dnia 10 grudnia 1929 roku (Nr III 1 Rw 77/29), w sprawie wcześniej rozpatrywanej przez Sąd Okręgowy w Przemyślu (Cg I c) 322/27) i Sąd Apelacyjny we Lwowie (Bc III 297 i 298/28), domagać się zniesienia współwłasności odziedziczonej nieruchomości ${ }^{16}$.

Czasami nawet wpisanie danej osoby w księdze gruntowej jako właściciela tabularnego nie gwarantowało w stu procentach, że ma ona tytuł prawa własności do gruntu wpisanego do księgi. Zgodnie z orzeczeniem Izby III Sądu Najwyższego z dnia 7 listopada 1923 roku (Rw. 2123/22) w sprawie wcześniej rozpatrywanej przez Sąd Powiatowy w Kałuszu (C. VII 243/21) i Sąd Okręgowy w Stanisławowie (Bc. III 522/22) tytuł prawa własności opierający się na prawie dziedziczenia mógł być wykazany tylko drogą postępowania sądowego. Nie dawała takiego prawa deklaracja właściciela tabularnego, mylnie wpisanego do księgi gruntowej, który następnie, zeznając $\mathrm{w}$ toku postępowania sprostowawczego ( 33 ustawy z dnia 23 maja 1883 roku, d.p.p. nr 82), usiłował przenieść je na osoby domniemanych dziedziców ${ }^{17}$.

Ważne również ze względu na zniszczenia w czasie I wojny światowej różnych dokumentów było orzeczenie Izby III Sądu Najwyższego z dnia 22 października 1926 roku (Rw. 1051/26), która stwierdziła, że grunty, których wykaz hipoteczny doznał w czasie wojny zniszczenia, nie tracą przez to charakteru rzeczy nieruchomej ${ }^{18}$. Orzeczeniem zaś z dnia 23 lutego 1926 roku (III R. 43/26) Sąd Najwyższy

13 Patent niesporny. Postępowanie w sprawach niespornych. Patent Cesarski z dnia 9 sierpnia 1854 roku (d.p.p. nr 208).

14 PPiA, „Orzecznictwo w zakresie Małopolski” 48, 1923, s. 283.

15 L. Górnicki, Prawa rzeczowe..., s. 326.

16 PPiA, „Orzecznictwo w zakresie Małopolski” 55, 1930, poz. 110, s. 179-181.

17 PPiA, „Orzecznictwo w zakresie Małopolski” 49, 1924, s. 6-7.

18 PN 6, 1927, nr 2, s. 199. 
uchylił wcześniejsze orzeczenia w tej sprawie Sądu Powiatowego w Kopczyńcach (A. IV 283/25) i Sądu Okręgowego w Czortkowie (R. 273/25), które odmówiły zrekonstruowania zaginionych akt spadkowych, a w szczególności ustalenia treści zaginionego ustnego testamentu z powodu, że ze świadków tego testamentu żyje tylko jeden świadek. Sąd Najwyższy uchylił te orzeczenia i powołując się na $§ 722$ ABGB stwierdził, że nawet jeżeli pisemne rozporządzenie ostatniej woli zaginęło, to nie traci ono swej ważności, jeżeli w inny sposób zostanie udowodnione zaginięcie oraz treść dokumentu ${ }^{19}$. Na mocy $\S 58$ trzeciej noweli do ABGB postanowienia $\S 722$ ABGB miały także zastosowanie do wszystkich przypadków prawnych, które przed dniem 1 stycznia 1917 roku nie zostały załatwione prawomocnym wyrokiem albo przyznaniem dziedzictwa, albo porozumieniem stron.

Kwestia przywrócenia zniszczonych przez działania wojenne ksiąg publicznych przy sądach w Małopolsce Wschodniej, gdzie działania wojenne trwały o dwa lata dłużej niż w Galicji Zachodniej, była po rozciągnięciu na te ziemie jurysdykcji sądów polskich jedną z najpilniejszych spraw — ważną ze względu na obrót prawny i życie gospodarcze ${ }^{20}$. Największe jednak straty w tym zakresie miały miejsce w latach 1914-1915 podczas najazdu wojsk rosyjskich na Galicję, kiedy to uległy zniszczeniu księgi gruntowe wielu tamtejszych sądów, często przy udziale miejscowej i okolicznej ludności włościańskiej ${ }^{21}$. Wydarzenia te można określić mianem galicyjskiej „wielkiej trwogi”, na skalę trochę mniejszą niż w rewolucyjnej Francji.

Wpis prawa własności spadkobierców do księgi gruntowej miał niezwykle istotne znaczenie - był wpisem stanowczym tak długo, jak długo byli oni w niej wpisani i byli uznawani za prawnych właścicieli rzeczy nieruchomych ${ }^{22}$. Własność rzeczy nieruchomych traciło się, tylko gdy zgodnie z § 444 ABGB nastąpiło jej wykreślenie $\mathrm{z}$ ksiąg publicznych. Zgaśnięcie prawa własności mogło także nastąpić $\mathrm{z}$ woli właściciela, $\mathrm{z}$ ustawy i z orzeczenia sędziowskiego; przy czym na mocy $\S 445$ ABGB nastąpiło rozszerzenie zastosowania przepisów regulujących powyższe sposoby nabycia i utraty prawa własności także na inne prawa rzeczowe, dotyczące rzeczy nieruchomych. Gwoli przypomnienia należy tu jedynie dodać, że ABGB spadkobranie zaliczał do praw rzeczowych ${ }^{23}$.

19 PPiA, „Orzecznictwo w zakresie Małopolski” 51, 1926, poz. 97, s. 113-116. Orzeczenie to nie spotkało się jednak z pełną aprobatą innych sędziów.

20 J. Kister, Rekonstrukcja ksiag gruntowych, PN 7, 1928, nr 3, s. 248.

${ }^{21}$ K. Kowalski, Prawne zwyczaje ludowe w powiecie sadowym mielnickim, PPiA 44, 1919, s. 175.

22 Niezaintabulowanie danego gruntu zgodnie z orzeczeniem Sądu Najwyższego z dnia 29 października 1926 roku (Rw. 1051/26) nie odbierało mu przymiotu, że był nieruchomością; Kodeks cywilny zawierający obowiązująca $w$ okręgach sądów apelacyjnych $w$ Krakowie $i$ Lwowie oraz sądu okręgowego w Cieszynie ustawę cywilna, ustawy i rozporządzenia dodatkowe, z uwzględnieniem ustawodawstwa polskiego, oraz orzecznictwa Sądu Najwyższego, przekł. i oprac. W. Dbałowski, J. Przeworski, Warszawa 1927, s. 408.

23 T. Maciejewski, Historia ustroju i prawa sadowego Polski, Warszawa 2003, s. 277. 
Ponadto wpis do księgi gruntowej, że dana osoba nabyła nieruchomość, powinien był być zgodny z rzeczywistym stanem prawnym i faktycznym, po to, by wzbudzał zaufanie do ksiąg gruntowych. Był on ważny nie tylko dla innych osób, które wierzyły, że jest on zgodny z prawdą, ale szczególnie dla samego nabywcy nieruchomości, chociażby w drodze spadkobrania. Mógł się on na niego powoływać wobec innych osób, że jest jej właścicielem, chyba że, zgodnie orzeczeniem Sądu Najwyższego z dnia 22 lipca 1937 roku (C II 527/37) w sprawie wcześniej rozpatrywanej przez Sąd Okręgowy w Stanisławowie (I C 27/33) i Sąd Apelacyjny we Lwowie (I CA 577/36), który stwierdził, że nie może się na niego powoływać nabywca nieruchomości, która była sporna i którą miał on już w swoim faktycznym posiadaniu przed wytoczeniem mu powództwa dotyczącego spornej nieruchomości. Fakt ten podważał jego wiarygodność ${ }^{24}$. Podobnie nabywca nieruchomości, który działał w imieniu osoby trzeciej, kontrakt jednak i intabulację przeprowadził na własne imię, nie stawał się jej właścicielem, lecz właścicielem była osoba trzecia —o ile objęła wspomnianą nieruchomość w posiadanie ${ }^{25}$.

Mimo prawnego znaczenia wpisu prawa własności do księgi gruntowej, instytucja ta przez ludność Małopolski przeważnie była nieuznawana i lekceważona, nie miała dla ludności wiejskiej żadnego znaczenia, a próby nakłonienia jej do uregulowania stanu faktycznego ze stanem prawnym uznawała za szykanowanie ${ }^{26}$.

Przewidziana w ABGB ,zasada wpisu” nie zawsze (niestety) w praktyce była przestrzegana. Niewpisane do księgi gruntowej prawo własności osoby dzierżącej w danym momencie nieruchomość skutkowało z punktu widzenia prawnego tym, że była ona tylko jej posiadaczem. Takich sytuacji w Galicji w okresie międzywojennym było niemało ${ }^{27}$. Rodziło to zatem pytanie, czy posiadanie jest dziedziczne, czy nie. Kwestia ta, leżąca na pograniczu prawa rzeczowego i prawa spadkowego, i istniejąca w tym zakresie rozbieżność poglądów pociągały za sobą większą lub mniejszą chwiejność doktryny i niejednolitość praktyki na tym odcinku ${ }^{28}$. Koncepcja wyraźnego ustawowego rozstrzygnięcia zagadnienia dziedziczności posiadania znalazła wyraz w projekcie prawa rzeczowego przyjętym przez Podkomisję Prawa Rzeczowego Komisji Kodyfikacyjnej w 1937 roku. Artykuł 440 tego projektu przewidywał, że „spadkobierca wstępuje w posiadanie, jakie służyło spadkodawcy w chwili jego zgonu”, a dodatkowo art. 57 projektu przewidywał, że „powołując się na zasiedzenie, posiadacz może doliczyć do swego posiadania czas posiadania oso-

24 PPiA, „Orzecznictwo” 62, 1937, poz. 313, s. 499-500.

25 Por. orzeczenie Sądu Najwyższego z dnia 1 października 1930 roku (III 1 Rw. 1235/30), PN 11, 1932, z. 2, s. 299.

26 K. Kowalski, op. cit., s. 175.

27 Narastające rozbieżności pomiędzy wpisem do ksiąg gruntowych a rzeczywistym posiadaniem prawnym umożliwiały spekulacje gruntami i były szczególnie rozpowszechnione we wschodniej Galicji już przed I wojną światową; L. Górnicki, Problem prawnej ochrony..., s. 182-183.

28 Por. na ten temat E. Till, Faktyczny stan posiadania a zaufanie do ksiag publicznych, PPiA 44, 1919, s. 261-279. 
by, od której posiadanie na niego przeszło" 29 . Projekt ten pozostał tylko projektem, a zatem o dziedziczeniu posiadania decydowała praktyka, a nie prawo.

Mimo tak istotnego znaczenia prawnego intabulacji ABGB nie wprowadziła bezwzględnie zasady przymusu intabulacyjnego. Wynika to $\mathrm{z}$ postanowienia $\S 372$ ABGB oraz ze względów słuszności i celowości, które uznawała ona także w odniesieniu do nieruchomości będących przedmiotem ksiąg gruntowych, przewidując możność nabycia ich na własność drogą pozahipoteczną. Orzecznictwo sądów w Małopolsce uznawało także własność pozahipoteczną naturalną jako konieczność wypływającą z tego stanu rzeczy, że w byłej Galicji, szczególnie Wschodniej, niezgodność między stanem tabularnym a faktycznym była bardzo częstą sytuacją ${ }^{30}$. Dlatego też ścisłe przestrzeganie zasady księgowości opartej na przepisach $\S 431$ i $441^{31}$ ABGB prowadziłoby w następstwie do wielkiego utrudnienia obrotu nieruchomościami ze względu na panujące stosunki, a często również i do pokrzywdzenia, szczególnie wiejskiej ludności. W orzecznictwie jednak podkreślano, że do nabycia własności w drodze pozahipotecznej potrzebne było, oprócz ważnego tytułu nabycia (§ 424 i 425 ABGB), także oddanie rzeczy w fizyczne posiadanie $(\S 309 \text { i } 312 \text { ABGB })^{32}$.

Problemy z intabulacją w byłym zaborze austriackim mogą trochę dziwić Galicja była bowiem krajem rolniczym, w którym stan ekonomiczny odbijał się w stosunkach prawnych. Była obszarem, gdzie kontrakty i proces przeważnie były gruntowe, a zaciągnięte kredyty — hipoteczne, a nie osobiste. Istniejąca praktyka rodziła zatem pytanie o charakter prawa własności przenoszonej nieruchomości; czy było to prawo pochodne nabywane poprzez jego wpis do ksiąg gruntowych, czy faktycznie nabywane przez tradycję fizyczną. Istniejąca praktyka pokazuje, że chłopi galicyjscy raczej uważali, że jest to nabycie w drodze tradycji33 ${ }^{33}$.

Na skutek niezgodności między wpisem w księdze gruntowej a rzeczywistym posiadaniem danej nieruchomości przed I wojną światową w okręgu Wyższego Sądu Krajowego (późniejszego Sądu Apelacyjnego) we Lwowie miało miejsce około dziesięciu tysięcy zbędnych procesów sądowych ${ }^{34}$. Były one następstwem nie tylko spekulacji ziemią, ale także zapewne nieuporządkowania spraw związanych z posiadaniem i własnością nieruchomości przez osoby, które nabyły prawa do nich w drodze dziedziczenia. Podobna sytuacja w Galicji Wschodniej utrzymywała się także w okresie międzywojennym. Fryderyk Zoll w 1938 roku pisał na

29 S. Wójcik, Czy posiadanie jest dziedziczne?, [w:] Rozprawy prawnicze. Księga pamiatkowa dla uczczenia pracy naukowej Kazimierza Przybyłowskiego, red. W. Osuchowski, M. Sośniak, B. Walaszek, Kraków-Warszawa 1964, s. 515-517.

30 D. Malec, Notariat Drugiej Rzeczypospolitej, Kraków 2002, s. 130-134.

31 Par. 441 ABGB stanowił, iż nowy właściciel wstępuje w posiadanie prawne, skoro tylko dokument o prawie własności wpisano do księgi publicznej.

32 Por. orzeczenie Sądu Najwyższego z dnia 1 października 1930 roku..., s. 103-104.

33 E. Udziela, O wplywie ksiag gruntowych na stosunki prawne, „Czasopismo Prawnicze i Ekonomiczne" 4, 1903, s. 132, 137.

34 L. Górnicki, Problem prawnej ochrony..., s. 184. 
ten temat, że „stan ten pogorszył się w Polsce w województwach południowych znacznie, zwłaszcza od czasu podniesienia opłat stemplowych od przeniesienia własności [...], a także od wprowadzenia prawa o notariacie”. Chłopi w Małopolsce transakcje mające za przedmiot prawa na nieruchomościach przeważnie załatwiali przez ustne umowy i zmiany w posiadaniu ${ }^{35}$.

Warto przy tym przypomnieć, że tak zwana nowela o dzieleniu parcel, czyli rozporządzenie cesarskie z dnia 1 czerwca 1914 roku (Dz.U.P. nr 116 i 117), wprowadziła możliwość sporządzania aktów prawnych dotyczących nieruchomości protokolarnie przed sądami, jeżeli ich wartość nie przekraczała 200 koron i jeżeli intabulacja ich miała zaraz nastąpić ${ }^{36}$.

Zgodnie z $§ 9$ ustawy z dnia 25 lipca 1871 roku o księgach gruntowych (d.p.p. nr 95) w księdze gruntowej mogły być wpisane tylko prawa rzeczowe. Wspomniana ustawa jednakże posiadania i praw spadkowych nie zaliczała do praw rzeczowych i w związku z tym nie mogły być one intabulowane w księdze gruntowej37. Jednakże dokonywanie wpisów dotyczących dziedziczenia nieruchomości do ksiąg gruntowych następowało na podstawie przepisów ABGB, który dziedziczenie zaliczał do praw rzeczowych, a nie na podstawie ustawy o księgach gruntowych.

Jak zauważył jeden z cytowanych autorów, nowe ustawodawstwo - nie tylko austriackie — nie miało szczęśliwej ręki przy określaniu wymogów potrzebnych do przelania prawa własności co do nieruchomości z jednej osoby na drugą ${ }^{38}$. Przykładowo przepisy patentu niespornego z 1854 roku w tym zakresie oceniano jako zbyt elastyczne, do tego stopnia, że skutki tej elastyczności odbiegają czasami za daleko od tego, co było intencją ustawodawcy austriackiego. Prawo zawierania umów w przewodzie spadkowym w formie protokołu sądowego opierano na $\S 2$ pkt 11 pat. niesp., który przewidywał, że przy zawieraniu kontraktów musi się dbać o to, by zamiar stron wyrażano jasno, by nie było miejsca na nieporozumienia o prawnych skutkach umowy, by przestrzegano formy koniecznej dla jej ważności i by zapobieżono wszelkim sporom przez dokładne i jasne ułożenie dokumentów. W rzeczywistości niestety przepis ten interpretowano zbyt szeroko, niwecząc wszelkie zasady w nim zawarte ${ }^{39}$.

Intabulacja prawa własności nieruchomości w byłym zaborze austriackim w okresie międzywojennym w praktyce sprowadzała się do znanej zasady: „przepisy sobie, a życie sobie". Usprawiedliwiano to stwierdzeniem, że trudno było uwzględniać moment zaufania do ksiąg gruntowych, o których wiadomo było,

35 F. Zoll, op. cit., s. 30.

${ }^{36}$ E. Till, Nowela do kodeksu cywilnego austriackiego wprowadzona rozp. ces. z 12 października 1914 Dz.U. P. N. 276, Kraków 1915, s. 27.

37 W.L. Jaworski, Ustawy o księgach publicznych, t. 1. Powszechna ustawa o księgach gruntowych i instrukcya hipoteczna, Kraków 1897, s. 48-49.

38 E. Udziela, op. cit., s. 140.

39 B. Diakow, Patent niesporny z 8. VIII. 1854. a przymus z art. 82 pr. o not, PN 13, 1934, nr 22, s. 12. 
że są one w przeważającej części wadliwie złożone, a nie uwzględniać zdarzeń prawnych przenoszących własność nieruchomości przewidzianych w $\mathrm{ABGB}^{40}$. Podkreślano też, że bezwzględna zasada wpisu przewidziana w prawie była nieprzystosowana do warunków społeczno-gospodarczych w zakresie obrotu nieruchomościami w Polsce w okresie międzywojennym, powodując negatywne skutki. Usprawiedliwiały to nawet takie autorytety prawne jak Fryderyk Zoll i Stefan Grzybowski, którzy zwracali uwagę, że owszem, wprowadzenie wpisu konstytutywnego niewątpliwie wzmocniłoby wiarygodność ksiąg wieczystych, wiązało się jednak z poważnymi niedogodnościami, a nawet perturbacjami. W praktyce stanowiło niezwykle trudną materię. Zdawali sobie z tego sprawę kodyfikatorzy prawa rzeczowego w Drugiej Rzeczypospolitej. Z tej przyczyny nawet prace nad unifikacją prawa rzeczowego przebiegały wolno i ostrożnie ${ }^{41}$.

Międzywojenne doświadczenia związane z intabulacją prawa własności nieruchomości o tyle mają znaczenie, że obecnie obowiązujący w Polsce system ksiąg wieczystych ukształtowany został niewątpliwie pod wpływem rozwiązań austriackich i niemieckich ${ }^{42}$. Zachodzi między nimi jednak także jedna istotna różnica. O ile Sąd Najwyższy w okresie międzywojennym był skłonny przyjmować, że wpis do księgi jest formą tradycji, a osoba legitymująca się jedynie tytułem prawnym może być uważana za właściciela, o tyle współczesne orzecznictwo z reguły dość rygorystycznie nie dopuszcza do odstępstw od obowiązku intabulacji.

\section{THE PROBLEM OF INTABULATION OF PROPERTY RIGHTS IN POLAND (IN THE FORMER AUSTRIAN PARTITION) IN THE INTERWAR PERIOD}

\section{Summary}

Entering the property rights in the land book in the law of the former Austrian Partition in Poland in the interwar period, i.e. intabulation, was of great importance. It was one of the conditions for the effective transfer of that right. This also applies to the transfer of ownership of real estate by inheritance. In practice, unfortunately, it was often not carried out, which caused a discrepancy between the actual and legal state of ownership of real estate. Even the courts had to be reconciled with this situation. It occurred in the former Austrian partition, especially regarding the inheritance of peasant land, giving rise to many legal problems.

Keywords: ABGB, inheritance, intabulation, land book, transfer of ownership, ownership of real estate

40 A. Oleszko, Znaczenie tytulu prawnego sporzadzonego na gruncie kodeksu cywilnego austriackiego oraz niemieckiego dla oceny skuteczności nabycia własności nieruchomości z dniem 1 tycznia 1947 roku, „Rejent” 17, 2007, nr 3, s. 15-16.

${ }^{41}$ J. Kuropatwiński, Znaczenie wpisu w polskim systemie wieczystoksięgowym. Rozważania nad projektem reformy, s. 1, www.kw-komentarz.pl/uploads/artykuly/reforma_ksiag.pdf (dostęp: 9.01.2020).

42 T. Stawecki, op. cit., s. 208. 


\section{BIBLIOGRAFIA}

Blajer P., Traditio a zasada jawności obrotu nieruchomościami, [w:] Experientia docet. Księga jubileuszowa ofiarowana Pani Profesor Elżbiecie Traple, red. P. Kostański, P. Podrecki, T. Targosz, Warszawa 2017.

Blajer P., Z historii ksiag gruntowych (Grundbücher), „Studia Prawnicze. Rozprawy i Materiały” $2015, \mathrm{nr} 2$.

Breyer S., Przeniesienie własności nieruchomości, Warszawa 1975.

Diakow B., Patent niesporny z 8. VIII. 1854. a przymus z art. 82 pr. o not, PN 13, 1934, nr 22.

Drozd E, Przeniesienie własności nieruchomości, Warszawa-Kraków 1974.

Giżowski R., Złożenie dokumentu w sądzie celem nabycia praw rzeczowych na nieruchomości, PN 11, 1932, z. 2.

Górnicki L., Prawa rzeczowe, [w:] Synteza prawa polskiego 1918-1939, red. T. Guz, J. Głuchowski, M.R. Pałubska, Warszawa 2013.

Górnicki L., Problem prawnej ochrony własności nieruchomości, nie wpisanej do ksiag gruntowych w okresie zaborów i w Polsce niepodległej, „Prawo. Studia Historycznoprawne” 286, 2002.

Jaworski W. L., Ustawy o księgach publicznych, t. 1. Powszechna ustawa o księgach gruntowych i instrukcya hipoteczna, Kraków 1897.

Kister J., Rekonstrukcja ksiag gruntowych, PN 7, 1928, nr 3.

Kowalski K., Prawne zwyczaje ludowe w powiecie sadowym mielnickim, PPiA 44, 1919.

Kuropatwiński J., Znaczenie wpisu w polskim systemie wieczystoksięgowym. Rozważania nad projektem reformy, www.kw-komentarz.pl/uploads/artykuly/reforma_ksiag.pdf.

Maciejewski T., Historia ustroju i prawa sądowego Polski, Warszawa 2003.

Malec D., Notariat Drugiej Rzeczypospolitej, Kraków 2002.

Oleszko A., Znaczenie tytulu prawnego sporzadzonego na gruncie kodeksu cywilnego austriackiego oraz niemieckiego dla oceny skuteczności nabycia własności nieruchomości z dniem 1 stycznia 1947 roku, „Rejent” 17, 2007, nr 3.

„Przegląd Prawa i Administracji”, „Orzecznictwo” 62, 1937, poz. 85, 313.

„Przegląd Prawa i Administracji”, „Orzecznictwo w zakresie Małopolski” 48, 1923; 49, 1924; 51, 1926, poz. 97; 53, 1928, poz. 111; 55, 1930, poz. 110.

Stawecki T., Rejestry nieruchomości, księgi hipoteczne i księgi wieczyste od czasów najdawniejszych do XXI wieku, „Studia Iuridica” 2002, nr 40.

Till E., Faktyczny stan posiadania a zaufanie do ksiag publicznych, PPiA 44, 1919.

Till E., Nowela do kodeksu cywilnego austriackiego wprowadzona rozp. ces. z 12 października 1914 Dz. U. P. N. 276, Kraków 1915.

Udziela E., O wptywie ksiag gruntowych na stosunki prawne, „Czasopismo Prawnicze i Ekonomiczne" 4, 1903.

Wójcik S., Czy posiadanie jest dziedziczne?, [w:] Rozprawy prawnicze. Księga pamiątkowa dla uczczenia pracy naukowej Kazimierza Przybyłowskiego, red. W. Osuchowski, M. Sośniak, B. Walaszek, Kraków-Warszawa 1964.

Zoll F., Na marginesie projektu prawa rzeczowego. Zasada wpisu a posiadanie prawne, „Kwartalnik Prawa Prywatnego" 1, 1938, z. 1. 